Editorial

\title{
Eu sou eu e minhas circunstâncias
}

Marco Antonio Guimarães da Silva,Med.Dr.Sci.

marco@atlanticaedu.com.br
Com a aposentadoria, tardiamente, solicitada e com a dupla nacionalidade que me permite morar em qualquer pais da comunidade européia, começo a fazer as malas para viver, ao menos seis meses por ano, em Paris.

Não pretendo com esse editorial entoar cantos funebres para anunciar a minha desilusão com o país que me acolheu desde o nascimento. A minha intenção é a de, baseado nos fatos que exporei, justificar o parcial auto exilio que me imporei a partir desse ano.

Não sou insensivel à beleza da minha cidade e tampouco à gentileza, à amabilidade e à generosidade do povo que vive nesses trópicos. Para poder usufruir de todos os bons predicados que o Rio de Janeiro e o Brasil me oferecem, é preciso, no entanto, em primeiro lugar, estar vivo e e, em segundo lugar, livre de depressóes e outros sentimentos bloqueadores de uma mínima sensação de bem estar. Tais são os pensamentos que me assombram a partir das noticias que me chegam diariamente através da imprensa.

Com relação à falta de segurança, carrego no meu currículo a marca de dois assaltos a máo armada, o primeiro deles ocorrido ha trinta e sete anos e o outro há sete anos. Só nesse ano vivenciei, de forma muito próxima, duas situaçóes de violência: presenciei, exatamente ao meu lado, uma execução à luz do dia, e, recentemente, o prédio onde moro foi invadido por assaltantes, também durante o dia. Essa foi, aliás, a segunda invasão sofrida à minha casa, já que, há cerca de 6 anos, tive que realizar uma mudança forçada, pois o meu apartamento havia sido igualmente roubado, dessa vez, felizmente, na minha ausência. No que se refere às cenas de violência cotidiana, fui testemunha ocular de vários "arrastóes" (para aqueles que moram fora do Rio, podemos definir a palavra como um ato em que vários "cidadãos", de arma em punho, se juntam para fazer coleta de bens e pertences de outros cidadãos, normalmente na praia ou em congestionamentos).
Todos esses eventos ocorreram em Ipanema, bairro chic do Rio e Janeiro, onde as ruas são protegidas por seguranças privados e por inúmeros agentes da P2 (polícia secreta da PM). Não estou a falar de bairros menos favorecidos e das favelas, porque o cotidiano da violência desses lugares já é bem conhecido por todos nós e se tornou, de certa forma, uma situação "normal", já que acontece sobretudo nos bairros daqueles a quem não é dada a possibilidade de evasão ou protesto.

Estamos sujeitos a uma hieraquia de valores que não elegemos, numa sociedade em que os parcos momentos de felicidade correspondem à fragil segurança do náufrago que, ao por os pés em terra firme, se maravilha por encontrar chão.

O parágrafo acima foi baseado em uma obra do Nietzsche (A Gaia Ciência). Aproveito, assim, esse mesmo autor para, sem digressões, analisar brevemente a situação que levantei. Em Genealogia da Moral, essencialmente na primeira das tres partes, Nietzsche distingue a moral do senhor e a moral do escravo. O senhor é aquele que pode auto dirigir a sua vida sem necessidade do outro e é dono de si mesmo. O olhar do senhor dirige-se para si mesmo e para o mundo que trata de mudar para conseguir a sua auto realização. Já o olhar do escravo é dirigido para o senhor, de quem ele depende. Segundo o filosofo, é natural supor-se que o o bom é o que se auto realiza, o senhor; e o mau, aquele que náo consegue realizar-se, o escravo. O olhar do escravo é obliquo e se move por ressentimento, porque ele náo se manifesta de forma espontânea e livre, senão de forma reativa e coercitiva. Esse ressentimento acaba por provocar uma rebeldia submissa, originando o que Nietzsche chama de moral dos escravos. A partir daí os ressentidos, os escravos, se unem e se tornam dominadores e invertem $o$ olhar do mundo ao imporem os seus valores. A moral dos escravos ou a moral do rebanho triunfa, e com ela nasce a cultura do rebanho, onde o bom passa a ser o homem obediente e submisso, que não atua e não pensa por 
si mesmo e o mau passa a ser o autocrata, livre e poderoso e que passa a representar o perigo.

Essa pequena passagem da primeira parte do livro me leva a considerar a nossa situação da seguinte forma: somos escravos e parte de um rebanho. Temos como senhores, por um lado, as autoridades constituídas e por outro o banditismo representado pelos seus mais diversificados segmentos. $\mathrm{O}$ nosso enviesamento de olhar vai se formando pela desesperança nas tais autoridades, cujos padróes éticos, via de regra, não correspondem às nossas expectativas, e pela angústia de sabermos que podemos ter, a qualquer instante, uma arma apontada para as nossas cabeças .

Se ao menos essa submissáo imposta nos provocasse ressentimentos e rebeldias capazes de gerar movimentos para a solução dos problemas, talvez parte de nossas mazelas estivessem equacionadas. $\mathrm{O}$ que se vê, entretanto, é a apatia, a resignação ou fuga na procura de lugares mais seguros e menos indecentes.

Prefiro acreditar que as coisas ainda podem se arrumar por aqui, mas, para que possa assistir a essa melhora, preciso aumentar as minhas chances de estar vivo, pelo menos em cinquenta por cento.

Não sei se o seu ponto de vista coincide com o meu, mas não importa; porque os distintos pontos de vista não se excluem, eles se complementam, para formar a verdade. Como disse Ortega: há tantas realidades como pontos de vistas; uma coisa não é apenas aquilo que vemos com os olhos: cada um dos olhos vê uma coisa distinta e, às vezes, inclusive, elas se contradizem. 